\title{
Effects of Chitosan and Nitrite on the Poperties of Fermented Meat
}

\author{
Purnama DarmadjI and Masatoshi Izumimoto \\ Department of Agricultural Products Technology, \\ Faculty of Agriculture, Okayama University, \\ Okayama-shi 700
}

(Received November 22, 1993)

\begin{abstract}
The inhibitory effect of chitosan (0-1\%) against some spoilage bacteria in beef was examined. Chitosan (0.5-1\%) inhibited Micrococci, Staphylococci, Pseudomonades and Coliforms. This effect increased with increase in chitosan content and incubation time. The effects of combination of three treatments ; chitosan $(0.5 \%)$, Lactobacillus plantarum starter culture and nitrite $(100 \mathrm{ppm})$ on the properties of Gram-negative bacteria, lipid oxidation (TBA value), residual nitrite and color quality in meat patties during fermentation at $30^{\circ} \mathrm{C}$ were also compared. Treatment of meat with chitosan or Lactobacillus plantarum inhibited the growth of Gramnegative bacteria by $1 \log$ cycle, repressed TBA value by $30 \%$ and $8 \%$ and dissipated residual nitrite by $52 \%$ and $60 \%$, respectively. Nitrite treatment inhibited the TBA value and the development of meat color, but had no significant effect on the growth of Gram-negative bacteria. The use of the three treatments together inhibited Gram-negative bacteria by about 2 log cycles, repressed TBA value by $36 \%$, dissipated residual nitrite by $63 \%$ and resulted in better color of fermented meat. These results indicated that chitosan could provide meat's protection against spoilage bacteria and could repress its TBA value particularly when combined with nitrite and Lactobacillus plantarum fermentation.
\end{abstract}

Anim. Sci. Technol. (JPn.) 65 (7) : 636-646, 1994

Key words : fermented meat, chitosan, Lactobacillus plantarum, TBA, residual nitrite, color

Chitosan, a waste product of the shellfish industry, has been shown to be non toxic ${ }^{2)}$, safe $\mathrm{e}^{11)}$ and to increase IgM production in human hybridoma cells ${ }^{21}$. Chitosan already has a number of uses in the food industry. It has been patented as a lipid binding food additive $^{9)}$, demonstrated its emulsion properties and dye binding capacity ${ }^{17-19}$. In the preservation of fruits, it has been used as a coating and antifungal agent, resulting in increased quality and storability of fresh strawberries ${ }^{10)}$. It has also been used for the reduction of titratable acidity and color index of carrot and apple juices ${ }^{12)}$. The antimicrobial activity of chitosan has been described by Papineau $e t a l{ }^{24)}$ and Sudarshan $e t$ al. ${ }^{28)}$. The utilization of chitosan for the development of the preservative qualities of meat has been presented by DARMADJ et al. ${ }^{7}$. Also, chitosan has shown an antimicrobial activity against meat spoilage bacteria and repressed its TBA value. For the developemnt of the preservative quality of traditional fermented meat products, Lactobacillus plantarum have been used as a starter culture. Its addition inhibits the growth of some spoilage bacteria, represses TBA value, dissipates residual nitrite and develops the preservative qualities of meat products ${ }^{6}$.

Sincce fermented meat products generally contain nitrite as a curing agent for color and flavor developemnt as well as preservative 
effect, this investigation describes a study on the inhibitory effect of chitosan against some spoilage bacteria in meat, and a study on the effects of chitosan and nitrite on the properties of meat fermented with Lactobacillus plantarum.

\section{Materials and Methods}

Beef samples were purchased from the local market on the day of preparation. Meat was cut and minced through a $4 \mathrm{~mm}$ plate diameter with a meat grinder. The starter culture used was Lactobacillus plantarum IAM 1216. Chitosan was obtained from Katokichi Co., Ltd. Japan.

The inhibitory effect of chitosan against some spoilage bacteria in meat: Each $10 \mathrm{~g}$ sample of minced meat was mixed with chitosan $(0,0.2$, $0.5,1 \%)$ in three replications. Each sample was then wrapped with saran wrap (Asahi Kasei Co., Ltd.) and incubated at $30^{\circ} \mathrm{C}$ for 12 or $24 \mathrm{~h}$. For the measurement of the inhibitory effect of chitosan, $10 \mathrm{~g}$ of each sample was dissolved in $90 \mathrm{ml}$ of sterilized phosphate buffered saline and homogenized with Physcotron (Nition Co., Ltd.). One $\mathrm{m} l$ of homogenates was taken and diluted stepwise with $9 \mathrm{~m} l$ of sterilized phosphate buffered saline. Appropriate diluents were placed on the following media ; Plate Count Agar (PCA) (Difco Co., Ltd.) supplemented with $10 \% \mathrm{NaCl}$ for Micrococci $^{27)}$; Vogel Johnson Agar (Eiken Ltd.) for Staphylococci; Desoxycholate agar (Nissui Co., Ltd.) for Coliforms ${ }^{4)}$; and Bacto OF Basal medium (oxidation/fermentation medium; Difco Co., Ltd.) supplemented with $7.5 \mathrm{mg}$ of Nalidixic acid and $30 \mathrm{mg}$ of Novobiocin in $10 \mathrm{ml}$ of sterile distilled water for Pseudomonades.

OF Basal medium surface plates were incubated at $25^{\circ} \mathrm{C}$ for $48 \mathrm{~h}$. PCA pour plates were incubated $30^{\circ} \mathrm{C}$ for $48 \mathrm{~h}$. Vogel Johnson surface plates were incubated at $35^{\circ} \mathrm{C}$ for $48 \mathrm{~h}$. For Coliforms, pour plates were made of each dilution using $1 \mathrm{~m} l$ in Desoxycholate agar. After the pour plates solidified, they were cov- ered with an additional $5 \mathrm{~m} l$ of Desoxycholate agar, incubated at $35^{\circ} \mathrm{C}$ for $24 \mathrm{~h}$ and the red colonies were counted ${ }^{4)}$. The inhibitory effect was calculated, as ${ }^{23)}$;

Inhibitory effect :

$$
\left(1-\frac{\text { CFU of prepared sample }}{\text { CFU of control sample }}\right) \times 100 \%
$$

Effects of chitosan and nitrite on the quality of fermented meat: Minced meat was divided into 8 parts of each $10 \mathrm{~g}$ by combination with or without $0.5 \%$ chitosan, $100 \mathrm{ppm}$ nitrite and $1 \%$ (v/w) Lactobacillus plantarum (in YPG medium $^{23)}$; incubated at $30^{\circ} \mathrm{C}$ for $16 \mathrm{~h}, 10^{6} \mathrm{CFU}$ ). The samples with and without nitrite were described as cured meat and intact meat respectively. Each $10 \mathrm{~g}$ sample was placed in a sterilized plastic petri-dish $(35 \times 10 \mathrm{~mm}$; Corning, Iwaki Co., Ltd.). Samples were incubated at $30^{\circ} \mathrm{C}$ for 12 or $24 \mathrm{~h}$, and were used for micobial analysis, $\mathrm{pH}, \mathrm{TBA}$ and residual nitrite determination.

Microbiological analysis; Teng of each sample was dissolved in $40 \mathrm{~m} l$ of sterilized distilled water and homogenized with Physcotron. $\mathrm{pH}$ was measured with Twin compact $\mathrm{pH}$ meter B-112 (Horiba Co., Ltd.). The solution was then made up to $90 \mathrm{~m} l$ with sterilized distilled water and homogenized. Gram negative bacteria and Lactobacillus were analyzed using Crystal Violet Tetrazolium (CVT) agar (Eiken Ltd.) ${ }^{26)}$ and MRS agar (Oxoid Ltd.) in triplicates. The MRS pour and the CVT surface plates were incubated at $30^{\circ} \mathrm{C}$ for $48 \mathrm{~h}$.

Chemical analysis; Nitrite was determined by modified $\mathrm{AOAC}^{30)}$ methods as follows. The homogenate sample for the miorobial analysis was held for approximately 30 minutes for extraction. Ten $\mathrm{m} l$ of the homogenized sample was pippeted into a tube, heated in steam bath at $80^{\circ} \mathrm{C}$ for $2 \mathrm{~h}$ with occasional shaking, cooled to room temperature and filtered with Toyo filter paper No. 2. One $\mathrm{m} l$ of the filtrate was taken and diluted with $9 \mathrm{~m} l$ of distilled water for residual nitrite determination by adding of $0.5 \mathrm{~m} l$ sulfanilamide reagent and NED (Naph- 


\section{Effects of Chitosan on Fermented Meat}

tylethylenediamine) reagent and expressed as ppm of $\mathrm{NO}_{2}$. The other part of the homogenized sample was used for the determination of TBA (index as lipid oxidation) ${ }^{1,16)}$ and expressed as $\mathrm{mg}$ malonaldehyde $/ \mathrm{kg}$ meat.

Color; Each $40 \mathrm{~g}$ of meat samples was placed into plastic petri-dish $(60 \times 15 \mathrm{~mm}$; Corning, Iwaki Co., Ltd.), pressed and wrapped with saran wrap before closing with petri-cup. The color of the meat surface was measured with Reflectance Color Meter (CM-1000, Minolta Co., Ltd.) and expressed as $\mathrm{L}^{*}$ (lightness), $\mathrm{a}^{*}$ (redness) and $\mathrm{b}^{*}$ (yellowness) values.

Data analysis : Samples were indicated by the symbols, M, MC, ML, MCL, MCLN, MCN, MNL and MN. The symbols $\mathrm{M}, \mathrm{C}, \mathrm{N}$ and $\mathrm{L}$ represents meat, chitosan, nitrite and Lactobacillus plantarum, respectively. All data were evaluated statistically using Student- $t$ method.

\section{Results and discussions}

The inhibitory effect of chitosan against some spoilage bacteria in meat during incuba- tion at $30^{\circ} \mathrm{C}$ for $24 \mathrm{~h}$ is shown in Table 1. Micrococci, Staphylococci, Pseudomonades and Coliforms were inhibited by chitosan and the inhibition was greater with the increasing incubation time and chitosan concentration. The presence of chitosan inhibited slightly the growth of Lactobacillus as shown in Table 2. The growth of Gram-negative bacteria was also inhibited by the presence of chitosan as shown in Table 4. The mode of inhibition of chitosan on the growth of some bacteria might be due to the polycationic nature of chitosan interferes with negatively charged of macromolecules at the cell surface and interaction of chitodsan with membranes or cell wall components resulting in increasing permeability of the membranes and leakage of cell materials from tissue ${ }^{31}$. This condition enhances the flow of nutrients and may can facilitate pathogenic infection to the bacterial cell, which causes the inhibition of their growth. In addition, biosorbtion activities of chitosan ${ }^{20)}$ may remove some nutrient from the cell. The

Table 1. Inhibitory effect of chitosan against some spoilage bacteria in meat during incubation at $30^{\circ} \mathrm{C}$

\begin{tabular}{|c|c|c|c|c|c|c|c|c|}
\hline \multirow{3}{*}{\multicolumn{2}{|c|}{$\begin{array}{r}\text { Incubation } \\
\text { time } \\
\text { (h) }\end{array}$}} & \multicolumn{7}{|c|}{ Chitosan (\%) } \\
\hline & & \multirow{2}{*}{$\frac{0.0}{\log _{(/ g)} \text { CFU }}$} & \multicolumn{2}{|c|}{0.2} & \multicolumn{2}{|c|}{0.5} & \multicolumn{2}{|c|}{1.0} \\
\hline & & & $\underset{(/ g)}{\log C F U}$ & $\underset{(\%)}{\text { Inhibition }}$ & $\underset{(/ g)}{\log C F U}$ & $\begin{array}{c}\text { Inhibition } \\
(\%)\end{array}$ & $\underset{(/ g)}{\log C F U}$ & $\underset{(\%)}{\text { In hibition }}$ \\
\hline \multirow{3}{*}{$\begin{array}{l}\text { Pseudo- } \\
\text { monades }\end{array}$} & 0 & 3.65 & 3.61 & 8.8 & 3.60 & 11.1 & 3.60 & 11.1 \\
\hline & 12 & 5. 32 & 5.17 & 28.6 & 4.94 & 58.0 & 4. 82 & 68.6 \\
\hline & 24 & 5.66 & 5. 46 & 37.1 & 4.95 & 80.6 & 4. 28 & 95.8 \\
\hline \multirow{3}{*}{$\begin{array}{l}\text { Staphylo- } \\
\text { cocci }\end{array}$} & 0 & 3.17 & 3.08 & 20.0 & 3.00 & 33.3 & 2.84 & 53.3 \\
\hline & 12 & 5.00 & 4.57 & 63.9 & 4.15 & 86.0 & 3. 60 & 96.0 \\
\hline & 24 & 6.04 & 5.78 & 45.5 & 5.00 & 90.0 & 4. 78 & 94.5 \\
\hline \multirow[t]{3}{*}{ Coliform } & 0 & 3. 39 & 3. 32 & 16.0 & 3. 30 & 20.0 & 2. 85 & 72.0 \\
\hline & 12 & 5.43 & 5.40 & 7.4 & 5.36 & 14.8 & 4. 38 & 91.1 \\
\hline & 24 & 8.84 & 8.66 & 34.2 & 8.40 & 64.2 & 7.38 & 96.5 \\
\hline \multirow[t]{3}{*}{ Micrococci } & 0 & 4.23 & 4.23 & 0.0 & 4.20 & 5.8 & 3. 43 & 80.7 \\
\hline & 12 & 6.08 & 5. 08 & 90.0 & 4.60 & 96.6 & 3.60 & 99.6 \\
\hline & 24 & 7.46 & 6.20 & 94.5 & 5.74 & 98.1 & 4. 51 & 99.8 \\
\hline
\end{tabular}

Inhibition : $\left(1-\frac{\text { CFU of prepared sample }}{\text { CFU of control sample }}\right) \times 100 \%$

Values are means from triplicate samples. 
Table 2. Effects of chitosan, Lactobacillus plantarum and nitrite on the growth of Lactobacillus of meat during fermentation at $30^{\circ} \mathrm{C}$

\begin{tabular}{cccc}
\hline \hline & \multicolumn{3}{c}{ Log CFU/g of Lactobacillus } \\
\cline { 2 - 4 } Treatment & \multicolumn{3}{c}{ Fermentation time (h) } \\
\cline { 2 - 4 } & 0 & 12 & 24 \\
\hline M & $4.5^{\mathrm{a}}$ & $5.8^{\mathrm{a}}$ & $6.6^{\mathrm{a}}$ \\
MC & $4.3^{\mathrm{b}}$ & $5.4^{\mathrm{b}}$ & $6.4^{\mathrm{b}}$ \\
ML & $6.5^{\mathrm{c}}$ & $7.7^{\mathrm{c}}$ & $9.0^{\mathrm{c}}$ \\
MCL & $6.5^{\mathrm{c}}$ & $7.5^{\mathrm{d}}$ & $8.1^{\mathrm{d}}$ \\
MCLN & $6.5^{\mathrm{c}}$ & $7.5^{\mathrm{d}}$ & $8.1^{\mathrm{d}}$ \\
MCN & $4.3^{\mathrm{b}}$ & $5.3^{\mathrm{b}}$ & $6.0^{\mathrm{e}}$ \\
MLN & $6.4^{\mathrm{c}}$ & $7.7^{\mathrm{c}}$ & $8.9^{\mathrm{c}}$ \\
MN & $4.3^{\mathrm{b}}$ & $5.8^{\mathrm{a}}$ & $6.6^{\mathrm{a}}$ \\
\hline
\end{tabular}

The different superscript letter within column are significantly different $(\mathrm{p}<0.05)$ for triplicate samples.

Treatment

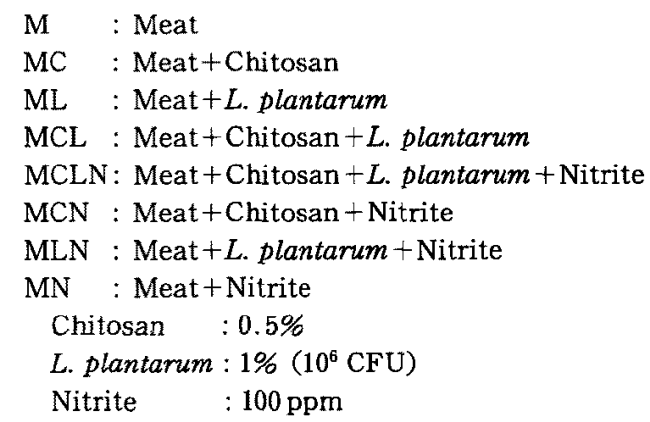

binding activity of chitosan toward DNA can inhibit mRN.A and protein synthesis and it's polycations may also play a role in the activation and inactivation of various enzymes ${ }^{18}$. These conditions may cause the inbalance in the bacterial cell system leading to the growth inhibition effect observed here.

Since Gram-negative bacteria are generally spoilage bacteria in meat, their growth depression by chitosan may prolong the shelf-life of meat.

The effect of chitosan on the $\mathrm{pH}$ of meat is shown in Table 3. Meat containing chitosan had higher $\mathrm{pH}$ than meat with no chitosan. That was due to the ability of chitosan to prevent excessive acid production ${ }^{12)}$ and also
Table 3. Effects of chitosan, Lactobacillus plantarum and nitrite on $\mathrm{pH}$ of meat during fermentation at $30^{\circ} \mathrm{C}$

\begin{tabular}{llll}
\hline & \multicolumn{3}{c}{ Fermentation time (h) } \\
\cline { 2 - 4 } Treatment $^{\mathrm{l}}$ & 0 & 12 & 24 \\
\hline M & $6.0^{\mathrm{a}}$ & $5.8^{\mathrm{a}}$ & $5.7^{\mathrm{a}}$ \\
MC & $6.2^{\mathrm{b}}$ & $5.9^{\mathrm{b}}$ & $5.8^{\mathrm{b}}$ \\
ML & $5.8^{\mathrm{c}}$ & $5.2^{\mathrm{c}}$ & $4.6^{\mathrm{c}}$ \\
MCL & $6.1^{\mathrm{d}}$ & $5.6^{\mathrm{d}}$ & $5.2^{\mathrm{d}}$ \\
MCLN & $6.2^{\mathrm{b}}$ & $5.6^{\mathrm{d}}$ & $5.2^{\mathrm{d}}$ \\
MCN & $6.3^{\mathrm{e}}$ & $5.9^{\mathrm{b}}$ & $5.6^{\mathrm{e}}$ \\
MLN & $5.9^{\mathrm{c}}$ & $5.3^{\mathrm{e}}$ & $4.6^{\mathrm{c}}$ \\
MN & $6.0^{\mathrm{a}}$ & $5.7^{\mathrm{f}}$ & $5.7^{\mathrm{a}}$ \\
\hline
\end{tabular}

The different superscript letter within column are significantly different $(p<0.05)$ for duplicate samples.

${ }^{1)}$ Symbols are same as shown in Table 2.

Table 4. Effects of chitosan, Lactobacillus plantarum and nitrite on the growth of Gram-negative bacteria in meat during fermentation at $30^{\circ} \mathrm{C}$

\begin{tabular}{cccc}
\hline \hline & \multicolumn{2}{c}{ Log CFU/g of Gram-negative bact. } \\
\cline { 2 - 4 } Treatment $^{1)}$ & \multicolumn{3}{c}{ Fermentation time (h) } \\
\cline { 2 - 4 } & 0 & 12 & 24 \\
\hline M & $4.6^{\mathrm{a}}$ & $6.0^{\mathrm{a}}$ & $8.1^{\mathrm{a}}$ \\
MC & $4.5^{\mathrm{a}}$ & $5.8^{\mathrm{bc}}$ & $6.4^{\mathrm{b}}$ \\
ML & $4.7^{\mathrm{a}}$ & $5.7^{\mathrm{bd}}$ & $6.9^{\mathrm{c}}$ \\
MCL & $4.6^{\mathrm{a}}$ & $5.6^{\mathrm{d}}$ & $6.1^{\mathrm{d}}$ \\
MCLN & $4.6^{\mathrm{a}}$ & $5.6^{\mathrm{d}}$ & $6.1^{\mathrm{d}}$ \\
MCN & $4.5^{\mathrm{a}}$ & $5.8^{\mathrm{bc}}$ & $6.4^{\mathrm{b}}$ \\
MLN & $4.6^{\mathrm{a}}$ & $5.9^{\mathrm{ac}}$ & $7.0^{\mathrm{c}}$ \\
MN & $4.6^{\mathrm{a}}$ & $6.0^{\mathrm{a}}$ & $8.1^{\mathrm{a}}$ \\
\hline
\end{tabular}

The different superscript letter within column are significantly different $(\mathrm{p}<0.05)$ for triplicate samples.

1) Symbols are same as shown in Table 2.

due to by slight inhibition of Lactobacillus plantarum accounting for the mild decrease in $\mathrm{pH}$ value of meat treated with chitosan and Lactobacillus plantarum. This observation is importance in the manufacture of intermediate fermented meats since combination of chitosan and Lactobacillus plantarum resulted in the inhibition of meat spoilage microorganisms and 
prevented the $\mathrm{pH}$ decrease in meat.

The rate of lipid oxidation in meat was reduced by addition of chitosan and Lactobacillus plantarum as indicated by repression in TBA value of meat during fermentation at $30^{\circ} \mathrm{C}$ as shown in Table 5. The TBA value of meat containing Lactobacillus plantarum or chitosan decreased by $8 \%$ and $30 \%$, respectively. A combined treatment with of chitosan and Lactobacillus plantarum repressed the TBA value by $36 \%$. The TBA values of cured meat remained low throughout the experimental period. It is suggested that there could have been an interference reaction between TBA reactive substances and nitrite. However, the combined treatment with Lactobaillus plantarum and chitosan in cured meat resulted in lower in TBA value than that of control. Have been reported that Lactobacillus strains demonstrated the catalase activities which have ability to decompose hydrogen peroxide when grown in the meat ${ }^{3)}$. So, the inhibition of TBA value in meat prepared with Lactobacillus plantarum may be due to the production of catalase like substances which could retard oxidation, resulting in inhibition of lipid oxida-

Table 5. Effects of chitosan, Lactobacillus plantarum and nitrite on TBA value of meat during fermentation at $30^{\circ} \mathrm{C}$

\begin{tabular}{cccc}
\hline & \multicolumn{3}{c}{ mg Malonaldehyde/kg meat } \\
\cline { 2 - 4 } Treatment $^{\mathrm{s}}$ & \multicolumn{3}{c}{ Fermentation time (h) } \\
\cline { 2 - 4 } & 0 & 12 & 24 \\
\hline M & $1.42^{\mathrm{a}}$ & $2.78^{\mathrm{a}}$ & $4.33^{\mathrm{a}}$ \\
MC & $1.45^{\mathrm{a}}$ & $1.83^{\mathrm{b}}$ & $3.01^{\mathrm{b}}$ \\
ML & $1.46^{\mathrm{a}}$ & $2.45^{\mathrm{c}}$ & $4.00^{\mathrm{c}}$ \\
MCL & $1.46^{\mathrm{a}}$ & $1.75^{\mathrm{d}}$ & $2.80^{\mathrm{d}}$ \\
MCLN & $0.83^{\mathrm{b}}$ & $0.74^{\mathrm{e}}$ & $1.44^{\mathrm{e}}$ \\
MCN & $0.82^{\mathrm{b}}$ & $1.09^{\mathrm{f}}$ & $1.52^{\mathrm{fg}}$ \\
MLN & $0.82^{\mathrm{b}}$ & $1.03^{\mathrm{B}}$ & $1.48^{\mathrm{f}}$ \\
MN & $0.92^{\mathrm{b}}$ & $1.09^{\mathrm{f}}$ & $1.55^{\mathrm{a}}$ \\
\hline
\end{tabular}

The different superscript letter within column are significantly different $(p<0.05)$ for triplicate samples.

1) Symbols are same as shown in Table 2. tion.

The inhibition of TBA value of meat in the presence of chitosan might be due to the lipid binding activity of chitosan ${ }^{9)}$ which resulted in the prevention of lipids from oxidation. The amino group of chitosan can also react with volatile malonaldehyde to form a stable fluorophore ${ }^{29}$. However, in our experiment, chitosan was mixed with meat from at the beginning of experiment and as seen in Table 5. TBA value of sample treated with and without chitosan were the same at $0 \mathrm{~h}$. This result suggests that chitosan does not interfere with TBA reactive substances. It has been reported shrimp meat contain natural antioxidant ${ }^{25)}$ and may contain chitosan. This implies that chitosan has antioxidative properties. Whatever the exact mechanisms of the inhibitory effect on TBA value of meat is unknown, this results indicates that Lactobacillus plantarum and chitosan when added to meat could inhibit TBA values and are useful for the depression of lipid oxidation in fermented meat especially when applied in combined form.

Table 6 shows that residual nitrite in cured meat decreased immediately by about $20 \%$ and continued to decrease during fermentation at $30^{\circ} \mathrm{C}$. When nitrite was added to meat for

Table 6. Effects of chitosan, Lactobacillus plantarum on residual nitrite of meat containing nitrite during fermentation at $30^{\circ} \mathrm{C}$

\begin{tabular}{cccc}
\hline \hline & \multicolumn{3}{c}{ ppm of residual nitrite } \\
\cline { 2 - 4 } Treatment $^{1)}$ & \multicolumn{3}{c}{ Fermentation time (h) } \\
\cline { 2 - 4 } & 0 & 12 & 24 \\
\hline MN & $810^{\mathrm{a}}$ & $566^{\mathrm{a}}$ & $446^{\mathrm{a}}$ \\
MCN & $77.3^{\mathrm{b}}$ & $523^{\mathrm{b}}$ & $215^{\mathrm{b}}$ \\
MLN & $760^{\mathrm{c}}$ & $27.6^{\mathrm{c}}$ & $17.8^{\mathrm{c}}$ \\
MCLN & $76.2^{\mathrm{c}}$ & $27.1^{\mathrm{d}}$ & $15.7^{\mathrm{d}}$ \\
\hline
\end{tabular}

The different superscript letter within column are significantly different $(p<0.05)$ for triplicate samples.

${ }^{1)}$ Symbols are same as shown in Table 2. 


\section{DARMADJi and IzUMIMoto}

curing, less than $63 \%$ of residual nitrite could be detected after addition immediately ${ }^{6,22)}$ and the nitrite in cured meat was converted to nitrate, nitrosomyoglobin and gaseous nitrogen compounds ${ }^{22)}$. It was observed that, the residual nitrite of cured meat treated with chitosan and Lactobacillus plantarum decreased more than that of control. The lower $\mathrm{pH}$ by the action of Lactobacillus plantarum support the degradation of nitrite to nitric oxide reactive substances ${ }^{8}$. Nitrite could also have reacted with amino or glucosamine of chitosan to give unstable 2, 5-anhydroderivative ${ }^{5)}$. These action may have caused a decrease in the residual nitrite.

The effects of chitosan and Lactobacillus plantarum on the color of beef patties during fermentation at $30^{\circ} \mathrm{C}$ for $24 \mathrm{~h}$ are shown in Table 7. The $L^{*}$ value of both intact and cured meat samples containing chitosan was found to decrease. This might have been caused by the increase of water binding capacity ${ }^{18)}$, resulting in increased transparency and low lighthness ${ }^{15)}$. In fermented meat, the

Table 7. Effects of chitosan, Lactobacillus plantarum and nitrite on color of meat during fermentation at $30^{\circ} \mathrm{C}$

\begin{tabular}{|c|c|c|c|c|c|}
\hline $\begin{array}{l}\text { Fermentation } \\
\text { time }(\mathrm{h})\end{array}$ & Treatment $t^{1)}$ & $\mathrm{L}^{*}$ & $a^{*}$ & $\mathrm{~b}^{*}$ & Form $^{2)}$ \\
\hline \multirow[t]{8}{*}{1} & $M$ & $34.4^{\mathrm{ac}}$ & $11.6^{\mathbf{a b}}$ & $12.9^{\mathrm{ab}}$ & $R(>M)$ \\
\hline & $\mathrm{MC}$ & $31.8^{b}$ & $12.2^{\mathrm{a}}$ & $11.5^{\mathrm{a}}$ & $\mathrm{R}(>\mathrm{M})$ \\
\hline & ML & $35.2^{\text {ad }}$ & $11.3^{\mathrm{b}}$ & $12.6^{\mathrm{ab}}$ & $\mathrm{R}(>\mathrm{M})$ \\
\hline & MCL & $31.8^{\mathrm{bc}}$ & $13.8^{\mathrm{ab}}$ & 13. $0^{\text {abc }}$ & $\mathrm{R}(>\mathrm{M})$ \\
\hline & MCLN & $34.4^{\mathrm{ac}}$ & 7. $3^{c}$ & 13. $9^{b c}$ & M \\
\hline & $\mathrm{MCN}$ & $32.1^{\mathrm{b}}$ & 8. $2^{\mathrm{cd}}$ & 12. $6^{\mathrm{abc}}$ & $M$ \\
\hline & MLN & $36.2^{\mathrm{d}}$ & 8. $0^{\text {cd }}$ & 14. $8^{\mathrm{abc}}$ & $\mathrm{M}$ \\
\hline & $\mathrm{MN}$ & $36.2^{\mathrm{d}}$ & 8. $1^{\mathrm{d}}$ & $14.3^{c}$ & $\mathrm{M}$ \\
\hline \multirow[t]{8}{*}{12} & $\mathrm{M}$ & $35.7^{\mathrm{ac}}$ & 15. $4^{\mathrm{ac}}$ & 8. $7^{\mathrm{a}}$ & $\mathrm{R}$ \\
\hline & $\mathrm{MC}$ & 32. $5^{\text {acd }}$ & $15.4^{\mathrm{a}}$ & $6.6^{\mathbf{a}}$ & $\mathrm{R}$ \\
\hline & ML & $37.9^{b}$ & $12.6^{\mathrm{b}}$ & 8. $7^{a}$ & $\mathrm{R}(>>\mathrm{M})$ \\
\hline & MCL & $32.0^{\text {acd }}$ & $14.6^{c}$ & $7.8^{\mathrm{a}}$ & $\mathrm{R}$ \\
\hline & MCLN & $32.9^{c}$ & $24.6^{d}$ & $11.7^{6}$ & NO \\
\hline & $\mathrm{MCN}$ & $30.9^{d}$ & $25.3^{\mathrm{e}}$ & 12. $1^{\mathrm{b}}$ & NO \\
\hline & MLN & $37.8^{\mathrm{b}}$ & $24.1^{d}$ & 13. $1^{c}$ & NO \\
\hline & MN & $35.7^{\mathrm{e}}$ & $26.2^{\mathrm{e}}$ & 15. $0^{d}$ & NO \\
\hline \multirow[t]{8}{*}{24} & M & $37.9^{\mathrm{ae}}$ & $14.5^{a c}$ & 10. $1^{\mathrm{a}}$ & $\mathrm{R}$ \\
\hline & $\mathrm{MC}$ & $33.6^{\mathrm{b}}$ & $15.1^{\mathrm{a}}$ & $7.5^{b}$ & $\mathrm{R}$ \\
\hline & ML & $36.7^{\mathrm{ac}}$ & $12.5^{\mathrm{b}}$ & 10. $0^{\mathrm{a}}$ & $\mathrm{R}(>>\mathrm{M})$ \\
\hline & MCL & 34. $6^{\mathrm{b}}$ & 12. $9^{b c}$ & $10.0^{\mathrm{a}}$ & $\mathrm{R}$ \\
\hline & MCLN & $35.3^{b c}$ & $24.1^{\mathrm{df}}$ & 13. $9^{c}$ & No \\
\hline & $\mathrm{MCN}$ & $34.6^{b}$ & $26.5^{\mathrm{e}}$ & $15.1^{\mathrm{d}}$ & NO \\
\hline & MNL & 39. $6^{d}$ & $23.3^{\mathrm{d}}$ & 13. $1^{\mathrm{e}}$ & No \\
\hline & MN & $38.2^{c}$ & 24. $4^{\mathrm{f}}$ & $14.5^{\mathrm{d}}$ & NO \\
\hline
\end{tabular}

The different superscript letter within column and line are significantly different $(p<0.05)$ for triplicate samples.

1) Symbols are same as shown in Table 2.

${ }^{2)}$ Myoglobin forms, $\mathrm{R}$ : reduced form, $\mathrm{M}:$ met form, NO : nitric oxide form. Minor form is shown in the parenthesis. 
$L^{*}$ value was higher than in non-fermented meat. That was due to the decrease in the meat $\mathrm{pH}$ resulting in high lightness ${ }^{15)}$.

In intact meat, the $\mathrm{a}^{*}$ value increased during fermentation, due to the formation of reduced myoglobin. These results corresponds to the increase in reduced myoglobin under anaerobic condition ${ }^{13)}$.

In cured meat the $\mathrm{a}^{*}$ value just after addition of nitrite was lower than intact meat and increase sharply during fermentation. The color changes are due to the formation of metmyoglobin and followed by nitric oxide myoglobin $^{14)}$. Both intact and cured meat prepared with chitosan showed higher $\mathrm{a}^{*}$ value. The higher formation of reduced myoglobin by chitosan might be due to direct reducing action of myoglobin or the activation of metmyoglobin reductase in meat.

In conclusion, chitosan could protect fermented meat from bacterial spoilage, repress lipid oxidation, dissipate residual nitrite and result in better of color.

\section{Acknowledgment}

This work was supported in part by a Grant in-Aid (No. 04660306) for Scientific Research Fund of the Ministry of Education, Science and Culture, Japan.

\section{References}

1) ANDo, N. and K. YamauchI, Studies on oxidative rancidity in cooked meat. Jap. J. Zootech. Sci., 39 : 41-47, 1968.

2) ARAI, K., T. KINUMAKI and T. FuJITA, Toxicity of chitosan. Bull. Tokai Reg. Fish. Res. Lab., 56 : 89-94. 1986.

3) Bacus, J., Utilization of Microorganisms in Meat Processing. Research Studies Press Ltd., John Wiley \& Sons Inc. New York. 1984.

4) Becton Dickinson, BBL dehydrated culture media manual. Becton Dickinson Overseas Inc. Co.. Tokyo. 1983.

5) Cassens, R.G.,M.L. Greaser, T. Ito and M. LEe, Reaction of nitrite in meat. Food Technol., 19 : 46-57. 1979.

6) Darmadj, P.,M. IzUmimoto, K. Kataoko and T.
Mryamoto, Lactic fermentation effects on preservative quality of dendeng giling. J. Food Sci., 55 : 1523-1527. 1990.

7) Darmadj, P., M. Izumimoto, K. Kat aoka and T. MIYAMOTO, studies on chitosan as preservative quality agent of meat. 85th Annual Meeting Abstracts of the Jpn. Soc. of Zootech. Sci. 147. 1992.

8) Fujmaki, M., M. Emi and A. Okitani, Fate of nitrite in meat curing model systems composed of myoglobin, nitrite and ascorbate. Agric. Biol. Chem., 39 ; 371-377. 1975.

9) Furda, I., Nonabsorbable lipíd binder. U.S. Patent. No. 4,223,023. 1980. Cited in KNORR, D., Food Technol., 38 : 85-97. 1984.

10) Ghaouth, A.E., J. ARul., R. Ponnampalam and M. Boulet, Chitosan coating effect on storability and quality of fresh strawberries. J. Food Sci., 56 : 1618-1620, 1631. 1991.

11) Hirano, S., C. Itakura, H. Seino, Y. Akiyama, I. NONAKA, N. KAMBARA and T. KAWAKAMI, Chitosan as ingredient for domestic animal feeds. J. Agric. Food Chem., 38 : 1214-1217. 1990.

12) IMERI, A.G. and D. KNORR, Effects of chitosan on compositional data of carrot and apple juice. J. Food Sci., 53 : 1707-1709. 1988.

13) IzUmimoto, M.,R. Iwahara and H. MiURA, Effect of anaerobic packaging on color stability and lipid oxidations in meat. Jpn. J. Zootech. Sci., 53 : 474-479. 1982.

14) Izumimoto, M., The characterization and background of meat color appearance. Jpn. J. Zootech. Sci., 55 : 703-715. 1984.

15) IzUMmoto, M. and S. KAWASE, Influence of $\mathrm{pH}$ on meat color appearance. Obihiro University Research Report, 15 : 203-208. 1987.

16) Izumimoto, M.,K. Kataoka and T. Miyamoto, Mathematical approach for determining TBARS in meat extraction and distillation methods. Agric. Biol. Chem., 54 : 1311-1313. 1990.

17) KNORR, D., Functional properties of chitin and chitosan. J. Food Sci., 47 : 593-595. 1982.

18) KNORR, D., Dye binding properties of chitin and chitosan. J. Food Sci., 48 : 36-37, 41.1983.

19) KNORR, D., Use of chitinous polymers in food. Food Technol., 38 : 85-97. 1984.

20) KNORR, D., Recovery and utilization of chitin and chitosan in food processing waste management. Food Technol., 45 : 114-122. 1991.

21) Maeda, M., H. Murakami, $H$. Ohta and $M$. TAJIMA, Stimulation of $\operatorname{IgM}$ production in 
human-human hybridoma HB4C5 cells by chitosan. Biosci. Biotech. Biochern., 56 : 427431. 1992.

22) Miwa, M.E., A. OKitani and M. FuJimaki, Comparison the fate of nitrite added to whole meat, meat fraction and model systems. Agric. Biol. Chem., 40:1387-1392. 1976.

23) NAKAE, T., K. KATAOKA and T. Miyamoto, Manufacturing and biochemical properties of fermented ground meat product. Reports for Research Grants for Meat and Meat Products, Itohkinen, $5:$ 293-304. 1987.

24) Papineau, A.M., D.G. HoOver, D. KNorr and D.F. FARKAS, Antimicrobial effect of water soluble chitosan with high hydrostatic pressure. Food Biotech, 5 45-57. 1991.

25) PASQUEL, L.J.R. and J.K. BABBIT, Isolation and partial characterization of natural antioxidant from shrimp (Pandalus jordan). J. Food Sci., 56 : 143-145. 1991.

26) REDDY, S.G., R.L. HENRICKSON and H.C. Olson, The influence of lactic culture on ground beef quality. J, Food Sci., 35 : 787-791. 1970.

27) SteEle, J.E. and M.E. Stiles, Microbial quality of vacuum packaged sliced ham. J. Food Prot., 44 435-439. 1981.

28) Sudarshan, N.R., D.G. Hoover and D. KNORR, Antimicrobial action of chitosan. Food Biotech., 6 : 257-272. 1992.

29) WeIST, J.L. and M. KAREL, Development of a flouorescence sensor to monitor lipid oxidation, II. The kinetics of chitosan fluorescence formation after exposure to lipid oxidation volatiles. Food Biotech., 6 : 273-293. 1992.

30) Williams, S., Official methods of analysis, (Ellis, R.L., eds.) 14th ed. 431-443. Association of Official Analytical Chemists, Inc. Arlington, Virginia. 1984.

31) Young, D.H., H. KoHLE and H. Kauss, Effect of chitosan on membrane permeability of suspension cultured Glycine $\max$ and Phaseolus vulgaris cells. Plant Physiol., $70: 1449-1454$. 1982 .

\title{
発酵肉の性状に及ぼすキトサンおよび亜硝酸塩の影響
}

\author{
Purnama DARMADJI ・泉本勝利 \\ 岡山大学農学部, 岡山市 700
}

\begin{abstract}
牛肉にキトサンを添加して，腐敗細菌の抑制効果を比較した。キトサンは，Micrococci， Staphylococci, Pseudomonades, Coliform の順に, 経時的にキトサン濃度が高いほど抑制した。 キト サン, Lactobacillus plantarum スターター, 亜硝酸塩を組み合せて添加し, $30^{\circ} \mathrm{C} て ゙$ 発醉中の Gram 隆性 菌数, 脂質酸化 (TBA 值), 残留亜硝酸根, 色調の各性状について比較した。 キトサン添加および Lactobacillus plantarum 接種によって，TBA 值は $30 \%$ および $8 \%$ ，残留亜硝酸根は $52 \%$ および $60 \%$ に 各々低下し，そして Gram 陰性菌数は $1 / 10$ に抑制された．亜硝酸塩の添加で TBA 值が低くなり，色調 はよくなったが，Gram 陰性菌は抑制されなかった，キトサン，Lactobacillus plantarum および亜硝酸 塩を併用すると Gram 陰性菌数は $1 / 100$ に抑制され，TBA 值は $36 \%$ に，残留亚硝酸根は $63 \%$ に低下 し，色調がよくなることが認められた，キトサンは発醉肉の腐敗菌および脂質酸化を抑制するために有 用であり，とくにキトサン，Lactobacillus plantarum および亜硝酸塩の併用は效果的であった.
\end{abstract}

日畜会報，65（7）：639-646, 1994 